\section{Book Review: Gesammelte}

\section{Schriften 1933-1936.}

Mit ergänzenden Beiträgen

aus der Zeit des Zweiten

Weltkrieges by Carl

Schmitt, Duncker \&

Humblot, 2021, 572 pages.

ISBN 978-3-428-15762-4

\section{HUBERTUS BUCHSTEIN}

The history of the edition of Carl Schmitt's works is an example of strategic publishing policy. His writings from the Weimar Republic as well as his late articles and books have been republished several times. In contrast, his most infamous writings during the time of his collaboration with the Nazi government were kept in the archives. Political theorists and historians had to spent hours and days in libraries to find them in old Nazi papers and magazines such as Völkischer Beobachter, Westdeutscher Beobachter, Deutsches Volkstum, Deutsche Kolonialzeitung or Das Reich and other weird places. In comparison to the publication of his handwritten diaries and his exchanges of letters, it took the group of Schmitt-enthusiasts and the publishing house Duncker \& Humblot much longer, in fact until 2021, to make this part of Schmitt's rich printed heritage easily accessible for readers too.

The bibliography for the period between 1933 and 1945 lists altogether 106 monographs, booklets and articles by Schmitt. The new collection republishes 66 of them. Not included are those 40 monographs and articles - with a few exceptions which already have been republished either by Schmitt himself or after his death in two other collections, edited by Günter Maschke in the 1990s. Most of the articles in this volume were published between 1933 and 1936. The editors also added seven articles written between April 1938 and May 1944.

The topics of the articles in this collection range from forceful defenses of the new Hitler government and its terroristic policies and legal measures, to outspoken criticism of liberal legal theories, to changes in Nazi criminal law, to international law and to methodological reflections about constitutional law, the so-called 'concrete order thinking'. The supportive substance of these articles may not be new to any informed Schmitt reader; it is the language that makes this collection a must-read. If one did not know in advance that Schmitt was the author of these articles, one would simply assume that they were written by Goebbels or any other leading Nazi propaganda author. The language of most of the articles is pure Nazi-German without any nuances between the lines.
HUP

CORRESPONDING AUTHOR:

\section{Hubertus Buchstein}

Greifswald University, DE

buchstei@uni-greifswald.de

KEYWORDS:

Carl Schmitt; Nazi Germany; Antisemitism

TO CITE THIS ARTICLE: Buchstein, Hubertus. 2021. "Book Review: Gesammelte Schriften 1933-1936. Mit ergänzenden Beiträgen aus der Zeit des Zweiten Weltkrieges by Carl Schmitt, Duncker \& Humblot, 2021, 572 pages. ISBN 978-3-428-15762-4." Redescriptions: Political Thought, Conceptual History and Feminist Theory 24(2): 172-177. DOI: https://doi. org/10.33134/rds.356 
I want to focus in this review on Schmitt's views about Jews in his publications between 1933 and 1945. A number of authors have argued that his harsh words about Jews were not a form of racist anti-Semitism, but religious anti-Judaism (as if the Jewish victims would have cared for such a distinction). This collection gives a deeper insight into Schmitt's anti-Semitism. In addition, the texts give a striking example of his conceptual policy and his deliberate choice of words.

The published articles in this collection present Schmitt's anti-Semitism escalating in five stages between 1933 and 1936. Schmitt had already agreed with the first rapid steps of Nazi policy towards Jews even before he publicly professed his allegiance to the Nazi regime. He had noted in his diary that he was positively impressed by the boycott of Jewish stores declared by the NSDAP on 28 March 1933 under the pretense of a declaration of war by world Jewry - not without expressing his concern about some of his Jewish personal friends. This anti-Semitism was only to intensify in his lectures and written works after 1933 until 1936 and a closer look at his choice of words and arguments shows the systematic nature of that escalation.

The first stage can be named half-muted anti-Semitism. It begins with his article Das gute Recht der deutschen Revolution (The undeniable Right of the German Revolution, pages 28-31). Published on 12 May 1933, 12 days after he had joined the party, in the NSDAP rag Westdeutscher Beobachter. The article made clear that combating Jewry and Judaism were at the center of the 'national revolution' that Schmitt supported with his work on constitutional law. The concrete purpose of the article was to justify the 'Gesetz über die Wiederherstellung des Berufsbeamtentums' (Law for the Restoration of the Public Civil Service), which had been enacted three weeks before. All the topics Schmitt addressed were linked in one way or another to the 'Jewish question' through the polemic concept of Gleichartigkeit. The German word puts together Gleich (similar, same) and Art (kind, sort) into an adjectival noun, which translates into English as 'similarity' and 'homogeneity'. As a word it is associated most strongly with a shared cultural understanding, and it was used to express the thought that the Jews do not share the culture of the Aryans. Schmitt considered Gleichartigkeit to be the key to the 'entire body of laws at hand'. The new provisions on civil servants, attorneys and physicians 'cleanse public life of non-Aryan fremdgeartete (stranger in kind, foreign sort) elements', thereby securing 'the eigenvölkische Art (our own people kind or sort) of the coming German generations'. The differentiation between Gleichartigen and Fremdgearteten became the epitome of his political thought, as the following maxim from the May 1933 article makes clear: 'We learn once again to differentiate. Above all, we learn to differentiate friend and enemy'.

The second stage is an anti-Semitism expressed as a form of biologistic racism. It started with Schmitt's lecture at the Deutsche Juristentag in Leipzig in October 1933 (pages 57-69). He addressed his audience of 12,000 jurists as 'Dear Volksgenossen (comrade of my people)'. Schmitt spoke in the morning of October 3, whereas Hitler gave a concluding speech in the evening. Schmitt noted in his personal diary of that day: 'Wonderful speech of Hitler about the total state'. In his own speech Schmitt replaced the term he had previously used, Gleichartigkeit, with that of Artgleichheit (kind-sameness, sort-sameness). Comprised of the same components Art (kind, sort) and Gleich (similar, same) as the previous term, this Nazi term best translates into English in this context as 'racial similarity'. This is explained by the fact that the German term 'art' encompasses the semantic field of 'species', 'nature' (in the sense of 'character'), 'kind', 'sort', 'way' and 'manner', thus comprising both a biological and a cultural understanding. As Schmitt used the term in October 1933, however, he
Redescriptions: Political

Thought, Conceptual

History and Feminist

Theory

DOI: $10.33134 /$ rds.356 
bent its meaning in the direction of biology. For one thing, he declared Artgleichheit to be the 'key concept' of the new Nazi state because it was 'indispensable for reasons of legal systematics'. For another, he linked Artgleichheit with the concept of the Führer (the leader) (he had not done so previously with the concept of Gleichartigkeit): 'Führen (to lead) is not commanding; Führen is not a dictatorship; Führen is something that rests on the Artgleichheit of the Führer and those being led'.

Even if he added that the concept of Artgleichheit was 'basically clear' and had already 'prevailed', Schmitt again avoided defining the biological concept he had elevated to become the key concept more precisely. Instead, he offered concretisations that deliberately triggered associations among his audience. For example, he emphasised the legitimacy of the Nazi revolution and its new 'substantive' legality. Nazi legality had to be 'wesens- und artgetreu' (faithful to its own essence and kind, sort). And he added: 'We need not permit a Volk (a people) with a different opinion or mindset to lecture us about this'. In this way, Schmitt constructed a connection between Art (kind, sort) and Denken (thinking). The Artfremde (a person alien to the German Art) could not think in a German way, even if he or she wanted to do so. They could not leave behind the biological character with which they were endowed when they tried to adopt German cultural practices. The thrust of these words of Schmitt is unequivocal: it was Jewish jurists who remained alien to the substantive German manner of legal thinking.

At the end of his talk in Leipzig, Schmitt offered his audience another topic, the nomos. The will of the Führer was directly applicable law, and 'we' Nazis should not permit ourselves to be misled by sophistic antitheses about politics and law. Following the will of the Führer, Schmitt stated, 'is, as Heraclitus said, also a nomos'. The concept of the nomos was to replace the concept of the state and the liberal rule of law. With these words, Schmitt again evoked anti-Semitic associations: the concept of the nomos liberated German legal thinking from the allegedly Jewish way of thinking in terms of laws and its purported strictness, legal mercilessness and fetish for rules.

The third stage is that of explicit anti-Semitism. It was only now that Schmitt outrightly mentioned the Jews he was fighting by name. He did so for the first time in his essay Nationalsozialistisches Rechtsdenken (Nazi legal thinking, pages 156-165) in the spring of 1934, in which he presented a summary of German legal history from his perspective. In this view, the legal system in Germany during the Middle Ages was characterised by the type of the wise, experienced and just man of concrete-order thinking. This harmonious legal concord had been disrupted from the fifteenth century on, when a kind of legal thinking oriented toward Roman law began to prevail over time. With its abstract rules and difficult, delicate differentiations, it became a kind of book learning removed from the problems of practical life. Yet the 'normativist type of thinking' succeeded in achieving a breakthrough in Germany only in the nineteenth century. Schmitt traced the cause of this development back to the 'influx of the Jewish guest-Volk'. Schmitt mentioned two reasons why the Jews had played a decisive role in this fallacious development. First, "because of the Eigenart (characteristic) of the Jewish people, which for millennia has been living not as a state and on one soil, but only in the law and the norm, which in other words is most literally "existentially normativistic"'. Second, normativism was not only part of Jewish nature, but also in the Jews' practical interest. A 'Fremder (a stranger, an alien), a guest, a metic', Schmitt claimed, saw the right of a Volk hosting him 'solely from the viewpoint of legal certainty'. And, he continued, that was not even surprising, given that the Jew 'does not belong to the reality of the Volk, the reality in which he lives'. The Jew simply wants the law to be 'the schedule in order to know when and where he can embark or disembark'.
Redescriptions: Political

Thought, Conceptual

History and Feminist

Theory

DOI: $10.33134 /$ rds.356 
In the fourth phase, Schmitt expressed his anti-Semitism not only explicitly, but militantly. It began with Schmitt's commentary on the infamous Nuremberg Laws passed on 15 September 1935 at the 'Reich Party Convention of Freedom' held in Nuremberg. At the party convention, Hitler proclaimed the Reichsbürgergesetz (Reich Citizenship Law), the Reichsflaggengesetz (Reich Flag Law) and the Gesetz zum Schutze des deutschen Blutes und der deutschen Ehre (Law for the Protection of German Blood and German Honor). One new aspect of these laws was that they were no longer about 'non-Aryans', but explicitly about 'Jews'. According to the Nuremberg Laws, marriages 'between Jews and citizens of German or artverwandt (related) blood' were forbidden. In addition, Jews were banned from hiring 'Aryans' as domestic staff and for hoisting the Reich flag.

Two weeks after the laws were proclaimed, Schmitt commented on them for the Deutsche Juristen-Zeitung (pp. 282-284). He immediately granted the new laws the level of constitutional status and called them 'the constitution of freedom, the core of our German law today'. Countering 'Germany's enemies and parasites', countering the 'demon of Entartung (degeneration)' countering 'geistige Fremdherrschaft (rule by alien intellectual and spiritual culture)', the Nazi revolution had at last made the concepts of the constitution of the Reich 'German again'. For decades German jurists had been entangled in the 'conceptual web of un-German systems' and had surrendered to liberalism. This epoch of German legal history had now been brought to an end once and for all. At this point, Schmitt uttered an open threat to the Jews: 'The Führer has mentioned that in the event that the current regulation of the situation of the Jews does not achieve the desired result, there would be the possibility of a fresh review, and he presented the prospect that then, the solution of this question would be conferred to the party by means of a law. This is a serious warning'. Below the combative bluster, however, Schmitt was actually barely capable of saying anything at all about the characteristics distinguishing 'Aryan' and 'Jewish'. The only differentiating criteria he mentioned were categories devoid of content such as the 'voice of German blood' and 'German substance'.

Following the Nuremberg Laws, the anti-Semitic measures in the Reich were undergirded academically from various sides. Schmitt actively participated in these activities. During a trip to Italy in spring of 1936, he reflected in an article (pp. 333-334) about the greatest difference between German Nazi and Italian fascist legal science. He saw it in different approaches to 'the problem of race'. He went on praising the 'biological well-being' in the form of 'purity of blood' of the German Volk, which was the goal of the Nuremberg Laws. Schmitt's militant anti-Semitism culminated in the autumn of 1936. On 3 and 4 October 1936, a conference of Nazi legal scholars, took place under his direction in Berlin. Schmitt formulated three guiding principles in his inaugural lecture (pp. 482-491). He took the first from statements by Hitler about 'Jewish dialectics' in Mein Kampf. It was: 'By fending off the Jew, I fight for the work of the Lord'. In the second guiding principle, Schmitt stated that legislation on race had been successfully completed. But now, what remained was the following task: 'tireless education to keep the German Volk aware of the Jewish danger'. Thus, in the third guiding principle, he reminded his audience of the 'deadly poison' with which Jewry and Judaism had for decades permeated the German state and science unhindered. Schmitt demanded that his audience and the German legal community overall should take a significantly more combative stance toward Jewry and Judaism: 'A merely emotional antisemitism and general rejection of some particularly obtrusive and unpleasant Jewish phenomena are not enough; what is needed is security based
Redescriptions: Political

Thought, Conceptual

History and Feminist

Theory

DOI: $10.33134 /$ rds.356 
on knowledge'. Adolf Hitler had found such security based on knowledge even as a young man in Vienna before the war - Schmitt may have alluded to Hitler's wording 'antisemitism based on reason' here. Such security based on knowledge was also necessary because the Germans had proven especially susceptible to 'Jewish infection' in the past. It was only thanks to the scientific study of race that the difference between the Jews and all other Völker on the globe had finally been identified clearly.

In his closing remarks, Schmitt mentioned a number of concrete measures that had to be taken to make the knowledge gained from the scientific study of race and Rassenseelenkunde (race-psychology) applicable to the practice of law. He demanded that a bibliography be prepared with precise information about which legal author 'is a Jew and which is not a Jew'. Building on this work, the next step would be a 'cleansing of the libraries'; in this way, students were to be 'protected from confusion'. Third, the problem of citations was of decisive importance for Schmitt. Following a conference such as the one that had just concluded, it was 'no longer possible to quote a Jewish author like any other author'. It was nothing less than irresponsible to quote a Jewish author as an authority in any area of the law. Jews per se had no authority in German legal thinking. If a Jewish author was to be quoted nonetheless, then the word 'Jewish' had to be added. Then and there, Schmitt helped his audience get accustomed to this new practice of attaching a literary yellow star, speaking of the 'Jew Kelsen' and calling Friedrich Julius Stahl 'Stahl-Jolson' to indicate his Jewish descent. Mentioning the word 'Jewish', he claimed, would bring about a 'holy exorcism'. Fourth, Schmitt took on the question of future research into legal history. He suggested setting a number of dissertation topics examining the detrimental Jewish influence on legal thinking in Germany in the past. With reference to Hitler and his warning of 'Jewish dialectics' in Mein Kampf, Schmitt declared the Jew to be the 'mortal enemy of any true productivity of another Volk'.

Schmitt thus systematically developed his language to frame the fight against the alleged Jewish enemy. After he lost his prominent positions within the Nazi system in the end of 1936, Schmitt moved ahead into a fifth stage. Since 1937 he started to cloak his anti-Semitism in pseudoscientific terms. A first attempt is to be found in his 1937 lecture The State as a Mechanism in Hobbes and Descartes in which he believed he could prove the subversive influence of Jewish thinking using the example of Jean Bodin. Bodin had been familiar with kabbalistic writings and had therefore identified the Leviathan as an 'all-demanding Moloch or an all-trampling Golem'. According to Schmitt, it was imperative to conduct 'detailed historical research' on the kabbalistic utilisation of the myth of Leviathan. Schmitt claimed to fill this gap in two chapters of his book The Leviathan in the State Theory of Thomas Hobbes, which he published in 1938. In his article Behemoth, Leviathan und Greif from 1943 (pp. 520-527) he repeated his thesis that Jewish thought had killed, destroyed and torn the Leviathan vulgo the state - into pieces.

A curious piece in this collection is a legal opinion by Schmitt about the film industry (pp. 414-430). It is well known that Schmitt liked to go to movie theatres. He even watched the kitsch silent movie The Passion of the Virgin of Orleans more than 10 times. The legal question on the table in 1936 was: Who deserves the copyright in the new genre of sound film? The person who wrote the script, the director in the studio or the producer? According to Schmitt, one clear decision for all movies is necessary. He argues that the roles of the director and producer are nearly unimportant. The author is the main creative person and he deserves all the glory and royalties of a successful movie. Every movie shows the 'handwriting' of an author. However, Schmitt's
Redescriptions: Political

Thought, Conceptual

History and Feminist

Theory

DOI: $10.33134 /$ rds.356 
preference of the author as the real Führer in the film industry was not shared by the Academy for German Law. In 1939, they decided that the producer owns the copyright for sound movies.

The editors of the book are both Schmitt's traditional publishing house Duncker \& Humblot and the Carl-Schmitt-Gesellschaft. They deserve recognition for making the most aggressive Nazi writings more easily available to Schmitt scholars. They also deserve respect for their editorial policy. The volume includes only a few very brief editorial comments. This is a relief for all those readers who suffered through Günter Maschke's apologetic essays in his editions of Schmitt's writings on state theory and on international law. The editors of this volume simply let the articles speak for themselves.

It would be an important contribution to the global reception of Schmitt's work if the articles in this book would be translated into other languages too. The challenge of the task should not be underestimated however: Schmitt wrote most of the articles in the particular vocabulary and with the code words of Nazi-German.

\section{COMPETING INTERESTS}

The author has no competing interests to declare.

\section{AUTHOR AFFILIATION}

\section{Hubertus Buchstein}

Greifswald University, DE
Buchstein

Redescriptions: Political

Thought, Conceptual History and Feminist Theory

DOI: $10.33134 /$ rds.356

TO CITE THIS ARTICLE:

Buchstein, Hubertus. 2021.

"Book Review: Gesammelte Schriften 1933-1936. Mit ergänzenden Beiträgen aus der Zeit des Zweiten Weltkrieges by Carl Schmitt, Duncker \& Humblot, 2021, 572 pages. ISBN 978-3-428-15762-4." Redescriptions: Political Thought, Conceptual History and Feminist Theory 24(2): 172-177. DOI: https://doi.org/10.33134/ rds.356

Submitted: 19 October 2021 Accepted: 21 October 2021 Published: 16 December 2021

COPYRIGHT:

(c) 2021 The Author(s). This is an open-access article distributed under the terms of the Creative Commons Attribution 4.0 International License (CC-BY 4.0), which permits unrestricted use, distribution, and reproduction in any medium, provided the original author and source are credited. See http:// creativecommons.org/ licenses/by/4.0/.

Redescriptions: Political Thought, Conceptual History and Feminist Theory is a peer-reviewed open access journal published by Helsinki University Press. 